\title{
PEMANFAATAN MEDIA SOSIAL TERHADAP FENOMENA "HOAX" DI KALANGAN REMAJA MILENIAL (STUDI DI SMAN 1, KECAMATAN PLERET,BANTUL, YOGYAKARTA)
}

\author{
Dyaloka Puspita Ningrum \\ Program Studi Ilmu Komunikasi Universitas Widya Mataram
}

\begin{abstract}
Social media is the media of choice for information and communication used by today's millennial generation, especially for participants in the service consisting of 2 nd grade students of SMA N 1 Pleret, Bantul, Yogyakarta. Much of the phenomenon of cybercrime is the spread of hoaxes that need high attention and alertness.this service activity was conducted using speech, discussion and simulation methods. The government is trying though the UU ITE to prevent and reduce negative content's in cyberspace with sanctions and threats legally that can harm others. Young people as a generation of the nation must be able to take smart and wise actions from existing social problems. Dissemination of hoax news in the form of SMS broadcasts, job carrier or information in the form of social events in the community without any clear source has occurred and has become a boomerang for media users themselves. There have been many parties responsible and dealing with the legal umbrella. As the nation's successor, millennial adolescents must increase socialization activities and fight hoaxes as crimes in cyberspace without having to trust every photo and video circulating in the public.
\end{abstract}

Keywords : Social media, Hoax, UU ITE.

\begin{abstract}
Abstrak
Media sosial merupakan media pilihan untuk mencari informasi dan berkomunikasi yang digunakan oleh para generasi milenial sekarang ini, khususnya pada peserta kegiatan pengabdian yang terdiri dari siswa-siswi kelas 2 IPS SMA N 1 Pleret, Bantul, Yogyakarta. Banyak fenomena terkait cybercrime yaitu penyebaran Hoax yang perlu mendapatkan perhatian dan kewaspadaan yang tinggi. Kegiatan pengabdian ini dilakukan menggunakan metode ceramah, diskusi dan simulasi. Pemerintah berupaya melalui UU ITE untuk mencegah dan mengurangi konten-konten negatif di dalam dunia maya dengan sanksi dan ancaman secara hukum yang dapat merugikan orang lain. Para pemuda sebagai generasi penerus bangsa harus dapat mengambil tindakan yang cerdas dan bijak dari permasalahan sosial yang ada. Penyebarluasan berita hoax berupa sms broadcast, lowongan pekerjaan, ataupun informasi berupa peristiwa sosial di masyarakat tanpa ada sumber yang jelas telah banyak terjadi dan bahkan menjadi boomerang untuk para pengguna media itu sendiri. Telah banyak pihak-pihak yang tidak bertanggung-jawab dan berurusan dengan payung hukum. Sebagai penerus bangsa,
\end{abstract}


remaja milenial harus memperbanyak kegiatan sosialisasi dan melawan hoax sebagai kejahatan di dalam dunia maya tanpa harus mempercayai setiap foto dan video yang beredar di masyarakat banyak.

Kata Kunci : Media Sosial, Hoax, UU ITE

\section{PENDAHULUAN}

\subsection{Latar Belakang Masalah}

Menurut Everett M.Rogers (dalam Abrar, 2003:17-18), New media diartikan sebagai bentuk kemajuan teknologi yang menawarkan kepraktisan dan kemudahan di era baru saat ini. Indonesia merupakan salah satu negara yang masyarakatnya dapat dikategorikan sebagai bagian dari para pengguna (user) aktif di berbagai media massa yang ada, baik pada media konvensional maupun media mainstream.

Manusia sebagai mahluk sosial akan membutuhkan mahluk lain untuk berkomunikasi di dalam lingkungannya sehingga pada kehidupan modern saat ini peran media menjadi hal penting yang digunakan dalam berinteraksi antara satu orang dengan lainnya. Perkembangan zaman yang semakin canggih di berbagai aspek kehidupan telah membawa perubahan-perubahan yang begitu pesat terutama pada bidang ilmu pengetahuan dan teknologi (IPTEK).
New media diartikan sebagai bentuk kemajuan teknologi yang menawarkan kepraktisan dan kemudahan di era baru saat ini. Indonesia merupakan salah satu negara yang masyarakatnya dapat dikategorikan sebagai bagian dari para pengguna (user) aktif di berbagai media massa yang ada, baik pada media konvensional maupun media mainstream khususnya media sosial yang telah menjadi pilihan alternatif oleh semua orang.

Kehadiran suatu media dianggap sebagai sumber informasi utama yang cepat dan tepat sehingga dapat mempengaruhi tatanan stabilitas kehidupan sosial yang dapat dirasakan oleh berbagai lapisan masyarakat. Media sosial merupakan bagian dari new media di era global sekarang ini, seperti : facebook, twitter, line, whatsapp, instagram, youtube dan lain sebagainya yang dapat digunakan dengan mudah, dimana saja dan kapan saja. Segala aspek-aspek politik, ekonomi, hukum, budaya, pertahanan dan keamanan 
bahkan pendidikan sekalipun, baik pada tingkat regional ataupun di tingkat nasional hampir tidak pernah luput dari sorotan media setiap waktunya.

Tidak asing lagi masyarakat mendengar kata "hoax", yang diartikan sebagai berita atau pernyataan yang tidak valid sehingga akan membuat keadaan menjadi panik. Konten hoax sering kali muncul bahkan dapat menimbulkan beragam konflik karena diragukan kebenarannya dan dianggap merugikan pihak-pihak (pribadi, instansi ataupun kelompok) yang berkaitan dengan penyebaran hoax itu sendiri oleh orangorang yang tidak bertanggung-jawab.

Dalam penggunaan media sosial beberapa para penggunanya belum mengerti tata cara dalam mengaplikasikan media sosial yang baik dan benar. Pada dasarnya kembali lagi dengan perilaku pengguna media sosial tersebut. Ada beberapa hal yang harus diperhatikan di dalam dunia maya ketika memposting atau mengupload berita dan informasi yang nantinya dapat diakses oleh semua orang, kapanpun dan dimanapun ia berada termasuk di Yogyakarta.

Di era modern saat ini, hampir setiap negara memiliki peraturan terkait penggunaan teknologi (termasuk media sosial) tak terkecuali di Indonesia. Indonesia memiliki peraturan terkait penggunaan ITE yaitu UU ITE. UndangUndang ITE ini sendiri dibuat berdasarkan keputusan anggota dewan pada tahun 2008. Keputusan ini dibuat berdasarkan musyawarah mufakat untuk melakukan hukuman dan sanksi bagi para pelanggar terutama di bidang informasi teknologi elektronik (Hana Machacova, 2013). Untuk dunia maya atau lebih dikenal dengan cyber sudah semakin kita kenal dekat dengan kehidupan sehari-hari di kalangan masyarakat Indonesia. Keberadaan internet bagaikan pisau bermata dua.

Media sosial saat ini digunakan oleh setiap kalangan, mulai dari dewasa, remaja hingga anak-anak yang ada disetiap pelosok daerah di Indonesia. Para pemuda sebagai generasi bangsa harus cerdas dan kritis dalam menyaring dan memilah-milih arus informasi yang ada di media sosial guna meningkatkan kualitas diri agar tidak terjebak dari isu-isu yang berbumbu provokatif dan merugikan orang lain. Remaja milenial khususnya, sebagai pengguna media yang aktif dan identik dengan sesuatu yang instan serta 
tidak lepas dari peran media sosial itu sendiri.

Beragam hoax muncul pada media mainstream tersebut dan menjadi fenomena baru yang harus diatasi dengan sikap cerdas dan bijak oleh para penggunanya terutama pada kalangan remaja milenial. Penyebaran hoax dapat terjadi secara massive karena ketidaktelitian masyarakat dalam menerima informasi yang beredar. Sesuatu dianggap "viral" akan dengan mudah mempengaruhi aturan-aturan, norma dan budaya yang ada di negeri ini. Ruang terbuka lebih mudah menjadi akses sasaran penyebaran hoax yang dapat memicu aksi disintegratif bangsa apabila tidak dilandasi oleh referensi yang memadai.

Telah banyak contoh kasus pemberitan hoax yang ada di Indonesia. Suatu kelompok pemuda proaktif sangat dibutuhkan untuk mengajak masyarakat agar lebih cerdas dan bijak menggunakan media sosial terutama instagram melalui foto dan video terbaru yang terhubung dengan semua orang yang ada di berbagai belahan dunia. Presentasi gambar yang unik di instagram tanpa merugikan orang lain menjadi faktor keberhasilan kemajuan IPTEK seiring berjalannya arus globalisasi saat ini.

Hoax sekarang ini lebih banyak beredar di dalam media sosial karena dilengkapi dengan berbagai macam fitur foto dan video ter-update yang disediakan oleh aplikasi tersebut. Konten hoax yang tidak akurat dapat mengakibatkan propaganda dan tindakan cyberbullying yang sangat tidak bermanfaat. Pemanfaatan jejaring sosial dengan semena-mena tidak menutup kemungkinan seseorang tersebut, bisa dijerat oleh UU ITE dengan pasal-pasal yang ada (Undang-Undang ITE, 2010).

\subsection{Tujuan Pengabdian}

Kebijakan UU ITE yang telah dibuat oleh Pemerintah, diperuntukan bagi para pengguna media sosial agar lebih menaati sanksi dan aturan yang ada agar tidak merugikan pihak-pihak tertentu. Tujuan dari kegiatan pengabdian ini adalah untuk memahami dan mengaplikasikan pemanfaatan media sosial sebagai media mainstream saat ini di kalangan remaja milenial terhadap fenomena cybercrime khususnya penyebaran hoax yang semakin massive di dalam dunia maya. 


\section{METODE}

Tipe penelitian ini adalah menggunakan pendekatan kualitatif dengan metode deskriptif. Penelitian ini berorientasi pada fenomena atau gejala yang bersifat alami. Menurut Bungin (2008), deskriptif berusaha untuk menjelaskan makna-makna secara sistematis, faktual dan akurat yang berkembang apa adanya, tidak dimanipulasi oleh peneliti dan kehadiran peneliti tidak mempengaruhi dinamika pada objek tersebut. Pendekatan kualitatif dipilih untuk menjelaskan realitas sosial di lingkungan remaja milenial.

Metode yang digunakan dalam pelaksanaan kegiatan pengabdian ini menggunakan metode ceramah, simulasi, tanya jawab dan diskusi perihal pemanfaatan penggunaan media sosial terhadap munculnya cybercrime di era modern saat ini. Informan ditentukan dengan menggunakan teknik purposive, yang dipilih berdasarkan pertimbanganpertimbangan beberapa kriteria yang telah ditetapkan untuk mendapatkan informasi yang maksimal. Peserta kegiatan yaitu siswa dan siswi kelas 2 SMA N 1 Pleret, Bantul Yogyakarta yang berusia17 tahun keatas. Dalam penelitian ini, peneliti melakukan pengamatan dan studi kepustakaan serta berusaha memahami dan menganalisisnya dalam bentuk evaluasi kegiatan.

\section{HASIL DAN PEMBAHASAN}

Kemajuan teknologi pada umumnya membawa pergeseran digital terhadap proses penyampaian dan penerimaan pesan disetiap media massa yang ada berdasarkan kegunaan dan kepuasan khalayak. Aktivitas yang dulu dilakukan secara offline telah bermigrasi ke ruangruang online. Media sosial menjadi media komunikasi paling efektif, transparasi dan efisien yang digunakan masyarakat modern di era keterbukaan informasi yang semakin berkembang dan meluas karena dianggap kuat dalam membentuk opini publik

Program kegiatan Pengabdian Masyarakat Program Studi Ilmu Komunikasi Fakultas Ilmu Sosial dan Ilmu Politik Universitas Widya Mataram dilaksanakan pada hari kamis, 22 November 2018 pukul 09.30 s/d 10.30 WIB, bertempat di SMAN 1 Pleret, Kabupaten Bantul , Yogyakarta, yang diikuti oleh 65 peserta yang terdiri dari siswa dan siswi dari kelas 2 IPS. 


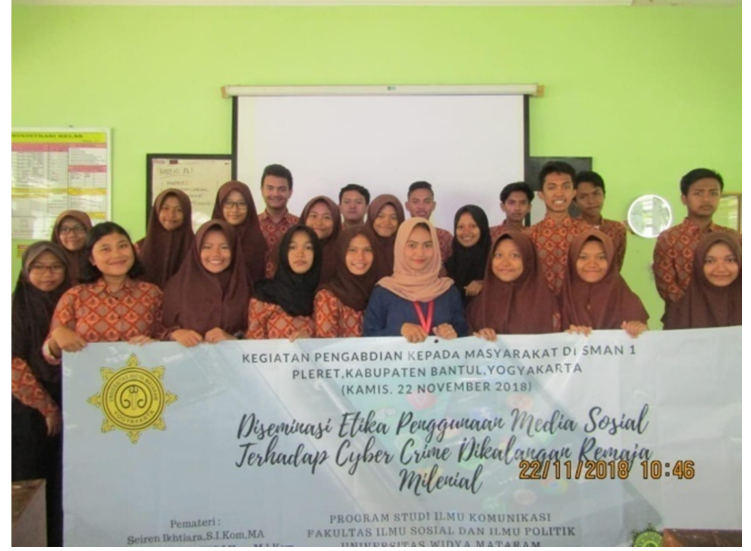

Gambar 3.1 : (Dokumen Pribadi, Kegiatan Pengabdian Masyarakat, Desember tahun 2018)

Materi yang disampaikan meliputi : Pentingnya pemahaman siswa terhadap pemanfaatan media mainstream saat ini, terutama pada maraknya kasus cybercrime yang tanpa batas ruang dan waktu telah banyak terjadi oleh pengguna media sosial, dikarenakan minimnya informasi tentang Undang-Undang Informasi dan Transaksi Elektronik (UU ITE) yang ada di Indonesia sebagai dasar negara hukum khususnya.

Berbagai fenomena terkait cyber crime yang perlu mendapatkan perhatian dan kewaspadaan yang lebih tinggi, dimana kejahatan yang dilakukan berbeda dengan kejahatan dalam dunia nyata. Cyber crime tidak membutuhkan adanya interaksi secara langsung antara pelaku dan korban kejahatan.

Telah banyak permasalahan mengenai fenomena Hoax yang semakin banyak terjadi dan sangat tidak bermanfaat keberadaannya. Sebagai contoh ada beberapa hoax yang sangat populer, seperti kasus Ratna Sarumparet, ataupun berita mengenai jatuhnya pesawat Lion Air JT 610 di tahun 2018.

Banyak informasi dan berita yang menyangkut-pautkan keadaan tersebut dari orang-orang yang tidak bertanggungjawab dengan cara menyebarluaskan foto ataupun video sejenis kepada masyarakat banyak.

Tidak adanya sosialisasi seputar cybercrime terhadap siswa-siswi SMA N 1 Pleret membuat mereka kurang memahami informasi mengenai kejahatan di dalam dunia maya, khususnya Hoax, serta regulasi dari Pemerintah yang mengatur ketentuan para pengguna media dalam kebebasan menyampaikan informasi berdasarkan UU ITE dengan adanya hukuman yang berlaku. Sehingga dari hal tersebut dapat memberikan referensi dan literasi kepada para remaja milenial di Kabupaten Bantul, Yogyakarta (temuan lapangan, tahun 2018).

Kejahatan cyber crime ini akan berimbas pada semua negara yang menggunakan internet, karena dapat 
merugikan berbagai pihak yang ada, baik secara individual maupun secara kelompok dari sisi immaterial.

Kejahatan-kejahatan di dunia maya banyak mengincar mereka yang sangat dekat dengan teknologi, tetapi tidak memiliki kemampuan yang bijak dalam menggunakannya, diantaranya adalah kaum remaja. Para remaja sebagai generasi milenial di era modern saat ini cenderung terlihat apatis atau terkesan tidak peduli terhadap lingkungan sosial karena telah banyak disajikan dengan segala sesuatu yang bersifat instan dan praktis.

Siswa-siswi SMA N 1 Pleret, menganggap kehadiran media sosial, menjadi pelengkap dalam proses komunikasi dan pencarian informasi dimanapun dan kapanpun mereka berada, tanpa mengkhawatirkan hambatanhambatan apa saja yang dapat ditemuinya dan juga dapat menjadi boomerang untuk diri mereka sendiri.

Hoax yang tersebarluar di media massapun, seringkali diterima mentahmentah oleh para remaja milenial, baik itu berisi sms broadcast, lowongan pekerjaan, ataupun informasi berupa peristiwa sosial di masyarakat tanpa ada sumber yang jelas (temuan lapangan, tahun 2018).

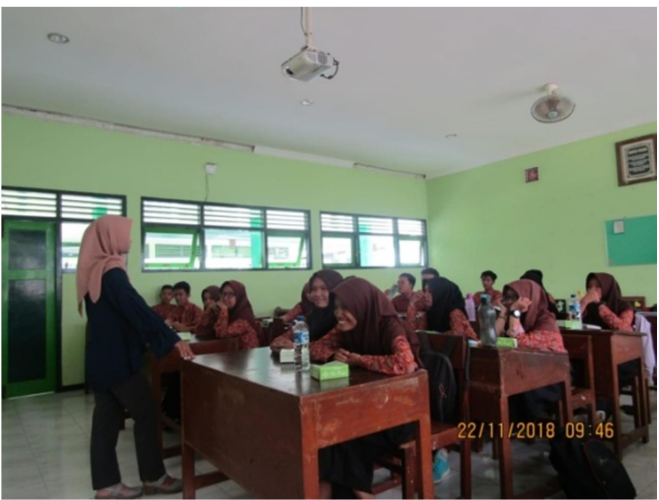

Gambar 3.2 : (Dokumen Pribadi, Penyampaian Materi Tentang Hoax, Desember tahun 2018)

Beragam hoax muncul pada media mainstream tersebut dan menjadi fenomena baru yang harus diatasi dengan sikap cerdas dan bijak oleh para penggunanya terutama pada kalangan remaja yang dikenal sebagai generasi milenial saat ini. Kontribusi para remaja harus didukung oleh segala pihak agar dapat membawa pengaruh menuju kehidupan masa depan lebih baik di tengahtengah permasalahan dan persaingan dari arus globalisasi yang semakin global, kompetitif dan komparatif disetiap aspekaspek kehidupan.

Kebebasan berpendapat di setiap media sosial yang ada sekarang ini melalui kolom "komentar" dan "like" cenderung memecah-belahkan publik. Kecepatan penyebaran informasi di media sosial tidak dapat disepelekan begitu saja. Generasi 
bangsa bersama-sama harus mampu mengiring warganet ke sejumlah akun grup diskusi online yang berisikan tentang penyuluhan anti hoax agar mendapatkan klarifikasi dari sumber-sumber yang jelas dan terpercaya setiap waktunya.

Ruang terbuka lebih mudah menjadi akses sasaran penyebaran hoax yang dapat memicu aksi disintegratif bangsa apabila tidak dilandasi oleh referensi yang memadai. Banyaknya fitur-fitur baru yang ditawarkan new media di zaman modern sekarang ini membuat dunia bebas tanpa batasan yang berisi orang-orang dari dunia nyata dapat berkreasi, berfikir dan membangun relasi melalui wadah di jejaring sosialnya.

Selain itu beragam aktivitas manusia di instagram memiliki andil yang sangat signifikan dalam mendigitalisasi perilaku manusia di ruang publik yang dapat disaksikan secara langsung "live" oleh berjuta pasang mata khalayak.

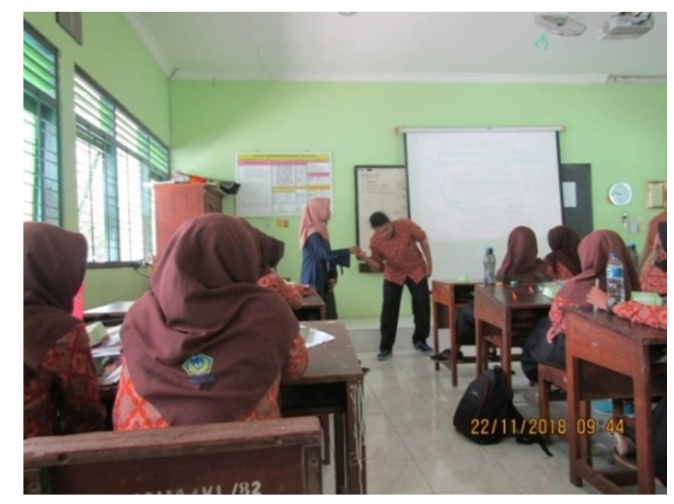

Gambar 3.3 : (Dokumen Pribadi, Proses Simulasi Penyampaian Hoax oleh Pemateri dan Peserta Kegiatan, Desember tahun 2018)

Pengalihan isu hoax dapat dilakukan juga dengan cara jangan gampang terhasut terhadap segala informasi yang beredar tanpa tahu kebenaran. Jadikan landasan hukum (UU ITE) yang ada sebagai pedoman untuk tetap baik dalam menggunakan media sosial.

Perbanyak kegiatan promosi nilai kebudayaan bangsa dan peningkatan kualitas diri melalui prestasi generasi muda yang jarang terekspose dari media sebelumnya. Perilaku pengguna media terhadap privasi dan haknya masingmasing menjadi suatu hal yang sangat sulit di kontrol, karena dapat dimasuki oleh orang lain secara bebas sehingga keadaan ini juga mampu menimbulkan bentuk-bentuk cyber crime yang akhirnya, setiap babak baru harus bisa dikendalikan oleh para generasi muda yang tumbuh bersamaan dengan maju dan menjamurnya teknologi.

Upaya pemerintah-pun melalui Undang-Undang (UU) ITE yang di dalamnya mengatur sanksi dan ancaman terhadap pihak yang menyebarkan konten negatif di dunia maya juga dapat 
disosialisasikan untuk meminimalisir bentuk-bentuk kejahatan di dalam dunia maya tersebut.

Kasus kejahatan yang ditampilkan media massa menunjukkan bahwa payung hukum dari pemerintah inilah yang membantu masyarakat Indonesia khususnya dalam membatasi penggunaan dalam mengakses internet dengan sebaikbaiknya.

Berdasarkan berbagai fenomena yang ada di negara ini, semakin menyadarkan kita tentang arti penting informasi dan pendidikan seputar media sosial terutama untuk remaja agar tidak terpuruk dan menjadi korban dari kejahatan-kejahatan dunia maya. Penanaman literasi media harus diupayakan oleh semua elemen, termasuk pengguna itu sendiri. Remaja saat ini harus dituntut untuk mampu berpikir kritis menyikapi segala kecanggihan teknologi yang melekat dalam kehidupannya seiring berjalannya arus globalisasi.

Dalam mencapai kesejahteraan dan kemakmuran suatu negara maka dibutuhkan para generasi muda yang siap dijadikan sebagai penerus cita-cita bangsa dengan kualitas dan potensi untuk dapat menyesuaikan diri seiring berjalannya arus globalisasi yang mampu mengikis dan mengancam jati diri bangsa Indonesia ke depan karena banyaknya nilai-nilai dan budaya baru yang masuk dan berkembang melalui keberadaan mediamedia di negeri ini.

Generasi muda merupakan bagian dari masyarakat yang produktif. Remaja harus mampu menggunakan teknologi secara bijak dengan mengutamakan utility serta menjauhkan diri dari hal-hal negatif. Remaja harus memiliki mindset positif dimana teknologi tercipta dengan tujuan awal untuk meningkatkan dan memudahkan pekerjaan manusia terkait pengaksesan maupun penyebarluasan informasi dan ilmu pengetahuan di setiap aspek-aspek kehidupan

\section{PENUTUP}

\subsection{KESIMPULAN}

Media memiliki kekuatan untuk menenggelamkan realitas, menyederhanakan berbagai isu, dan mempengaruhi berbagai peristiwa. Instagram merupakan bagian dari new media yang memiliki daya tarik dan mampu mengundang perhatian masyarakat terhadap realitas sosial berdasarkan jumlah pengguna yang terus 
meningkat setiap waktunya karena dapat mengemas informasi dengan semenarik mungkin.

Kehadiran media dengan segala aspek perkembangan teknologi yang semakin pesat sangat berpengaruh terhadap tindakan yang akan dilakukan oleh masyarakat. Ketergantungan publik akan informasi dan berita di media meanstream khususnya instagram mampu mengubah pola pikir khalayak menjadi lebih adiktif dalam mengelola media sosialnya. Di tengah arus globalisasi saat ini muncul suatu fenomena baru disebut dengan nama hoax.

Penyebaran konten hoax yang tidak jelas kebenarannya dapat merugikan pihak-pihak yang berkaitan dengan isu tersebut. Para pemuda khususnya para pelajar sebagai generasi penerus bangsa harus bisa mengambil tindakan yang bijak dan cerdas dari salah satu permasalahan sosial tersebut. Kelompok inilah yang diyakini dapat menghadapi tantangan global dan membawa opini publik agar tidak terlarut dari kekeliruan informasi yang beredar setiap waktunya.

Pesatnya penggunaan media sosial dikalangan remaja milenial / siswa-siswi SMA N 1 Pleret, membuat mereka menjadi aktif dalam mengakses segala sesuatu yang disebarluaskan oleh pihakpihak yang tidak bertanggung-jawab khususnya.

Kehadiran hoax yang semakin massive ditengah-tengah kehidupan masyarakat harus dilawan bersama-sama. Ketergantungan akan informasi dan berita di media mainstream mampu mengubah pola pikir remaja milenial menjadi lebih adiktif dalam mengelola media sosialnya.

Para penerus bangsa tersebut di diajak untuk dapat peduli dengan pencegahan bentuk-bentuk cyber crime di dalam dunia maya, serta mengajak semua siswa dan siswi untuk memahami etika dalam menggunakan dan memanfaatkan media sosial yang dilandasi oleh dasar hukum (UU ITE) yang ada di Indonesia.

\subsection{SARAN}

Untuk menghindari penyebarluasan informasi yang tidak jelas sumbernya, media sosial dapat dimanfaatkan para remaja milenial sebagai grup diskusi online bahkan secara langsung “.

Selain itu pengalihan isu hoax dapat dilakukan juga dengan cara perbanyak kegiatan promosi nilai kebudaaan bangsa dan peningkatan kualitas diri melalui prestasi generasi muda yang jarang terekspose dari media sebelumnya. 
Para siswa-siswi di SMA N 1 Pleret, harus meningkatkan pengetahuan bahkan literasi sebanyak-banyaknya mengenai peranan media sosial sebagai media mainstream saat ini dengan segala aturan hukum yang berlaku di dalamnya. Mengikuti kegiatan sosialisasi sangat bermanfaat untuk diri para remaja tersebut, dalam menghadapi arus informasi yang terus berkembang di era global saat ini.

Semua jenis berita dan issue yang berkembang di masyarakat sosial harus ditelaah dengan semaksimal mungkin untuk menghindari hoax yang ada tanpa batasan ruang dan waktu.

\section{DAFTAR PUSTAKA}

Abrar, Ana Nadya. 2003. Teknologi Komunikasi: Perspektif Ilmu Komunikasi. Yogyakarta: LESFI

Hana Machacova, dkk, Effectiviness of Coping Strategies for victims of cyberbullying, Journal of Psyhosocial Research on Cyberspace : Cyber Psychology, 2013

Reza. 2015. Pengguna Internet Indonesia Kuasai Media Sosial di 2015, dikutip dari http://tekno.liputan6.com/, diaksespadatanggal05 November 2018

UU ITE No.11 Pasal 27 Tahun 2008 (Undang Undang Informasi dan Transaksi Elektronik)

https://www.kominfo.go.id/content/detail /8566/mengenal-generasi-

millennial/0/sorotan media, diakses pada tanggal $01^{-}$november 2018 